\title{
RADIOCARBON DATING OF CALCINED BONES: INSIGHTS FROM COMBUSTION EXPERIMENTS UNDER NATURAL CONDITIONS
}

\author{
Antoine Zazzo $^{1,2} \cdot$ Jean-François Saliège ${ }^{1} \cdot$ Matthieu Lebon $^{3} \cdot$ Sébastien Lepetz $^{1} \bullet$ \\ Christophe Moreau ${ }^{4}$
}

\begin{abstract}
Radiocarbon dating of the carbonate remaining in calcined bones is widely regarded as a viable alternative to date skeletal remains in situations where collagen is no longer present. However, anomalously low $\delta^{13} \mathrm{C}$ values measured in calcined bones prompted questions about the origin of the carbon used for dating. The goal of this study was to quantify the magnitude of carbon isotope exchange between bone carbonate and environmental $\mathrm{CO}_{2}$ for bones calcined under natural conditions. Four archaeological bones ranging in age between the Neolithic and the Medieval period were combusted on a separate open fire for up to $4 \mathrm{hr}$ and subsamples of calcined bones were taken every hour. All the bones experienced a significant increase in IRSF values and decrease in carbonate content and $\delta^{13} \mathrm{C}$ values. ${ }^{14} \mathrm{C}$ ages measured in the carbonate fraction of well-calcined bones indicate that $67 \pm 3 \%$ to $91 \pm 8 \%$ of the carbon present in bone carbonate was replaced by carbon from the atmosphere of combustion. This finding confirms previous results obtained under laboratory conditions and has serious implications for ${ }^{14} \mathrm{C}$ dating of calcined bones found in archaeological contexts. The ${ }^{14} \mathrm{C}$ age obtained on a calcined bone will only reflect the true age of the bone sample if the age difference between the bone and the charcoal can be neglected. Our results show also that $\delta^{13} \mathrm{C}$ values of calcined bones can be used to estimate the degree of $\mathrm{C}$ exchange and control for postburial diagenetic alteration.
\end{abstract}

\section{INTRODUCTION}

Calcined bones are present in the archaeological record from the Paleolithic to the modern period. Bone combustion can be associated to different activities. Burned and calcined bones are found in domestic contexts, and sometimes in craft contexts, where they can be used as fuel thanks to their combustible properties (Théry-Parisot and Costamagno 2005; Lepetz and Fournet, in press). They can also be found in funerary contexts, in societies where the deceased undergoes a cremation process (Lanting et al. 2001; Van Strydonck et al. 2010; Lepetz and Van Andringa 2011). Human bones are included, but also animal bones when food offerings have been put on the pyre (Lepetz and Van Andringa 2008). Therefore, calcined bones are ubiquitous and carry important information regarding the economy of subsistence as well as the mentality of past human societies. Until the late 1990s, calcined bone was considered impossible to date because collagen, the main source of carbon present in bones, is degraded during heating. In their pioneer work, Lanting et al. (2001) showed a good consistency between ages obtained on the inorganic (carbonate) fraction of cremated bone apatite and coexisting charcoal in a number of Holocene sites from northern Europe, thus demonstrating the reliability of calcined bone for ${ }^{14} \mathrm{C}$ dating. Today, radiocarbon dating of calcined bones is widely regarded as a viable alternative to date skeletal remains in situations where collagen is no longer present. A recent compilation of the bone ${ }^{14} \mathrm{C}$ dates published in Radiocarbon over $50 \mathrm{yr}$ showed that $95 \%$ of the bone dates used collagen as a dating support. But when collagen is not available in sufficient quantity, calcined bone is favored over unburned bone or enamel, with $65 \%$ of all the dates obtained on the inorganic fraction (Zazzo and Saliège 2011). This preference is due to the fact that the physico-chemical changes occurring during calcination improve the bone resistance to diagenetic alteration and have a direct impact on their reliability for ${ }^{14} \mathrm{C}$ dating. At $\sim 600{ }^{\circ} \mathrm{C}$ and

\footnotetext{
${ }^{1}$ CNRS, UMR 7209, Archéozoologie, archéobotanique: sociétés, pratiques et environnements. Muséum national d'Histoire naturelle, Dép. EGB, CP56, 55 rue Buffon, F-75005 Paris, France.

${ }^{2}$ Corresponding author. Email: zazzo@mnhn.fr.

${ }^{3}$ CNRS, UMR 7194, Histoire naturelle de l'Homme préhistorique. Muséum national d'Histoire naturelle, Dép. préhistoire, 1 rue René Panhard, F-75013 Paris, France.

${ }^{4} \mathrm{LMC14}$, UMS 2572, CEA/Saclay, Bâtiment 450, porte 4E, 91191 Gif-sur-Yvette Cedex, France.
}

C 2012 by the Arizona Board of Regents on behalf of the University of Arizona Proceedings of the 6th International Radiocarbon and Archaeology Symposium, edited by E Boaretto and N R Rebollo Franco RADIOCARBON, Vol 54, Nr 3-4, 2012, p 855-866 
above, the small apatite crystals recrystallize and increase in size (Shipman et al. 1984; Holden et al. 1995). This recrystallization is accompanied by a loss in carbonate content of about $50 \%$ or more. This loss decreases the stress within the crystal structure and results in an increase in the crystallinity index as measured by X-ray diffraction or infrared spectroscopy (Shipman et al. 1984; Person et al. 1995; Munro et al. 2007; Zazzo et al. 2009). This improved crystallinity, together with a decrease in the surface area of the bone crystallites, acts as an effective barrier against the bicarbonate ions present in the fossilization milieu and therefore limits postdepositional isotopic exchange. Once they have recrystallized, calcined bones can be considered as a closed system at least for the Holocene.

The question of the origin of the residual inorganic carbon in calcined bones remained open for a long time. Indeed, heating causes significant changes in the isotope composition of the mineral fraction of bioapatites resulting in a sharp (up to $15 \%$ ) decrease in the bone $\delta^{13} \mathrm{C}$ value (Lanting et al. 2001; Van Strydonck et al. 2005; Olsen et al. 2008; Zazzo et al. 2009). The comparison of the $\delta^{13} \mathrm{C}$ of the charred (black) and calcined (white) portions of the same bone indicates that these modifications are highest in the calcined portions (Olsen et al. 2008). Recently, laboratory experiments performed on modern bones showed that bone ${ }^{14} \mathrm{C}$ activity was also modified during calcination (Hüls et al. 2010; Van Strydonck et al. 2010). Calcination of modern bone in the presence of old $\mathrm{CO}_{2}$ resulted in a decrease in bone ${ }^{14} \mathrm{C}$ activity, which paralleled the decrease in $\delta^{13} \mathrm{C}$ values (Hüls et al. 2010). These results demonstrate that carbon isotope exchange occurs during calcination between bone carbonate and the carbon present in the environment of combustion. Several parameters seem to control the intensity of $\mathrm{C}$ isotope exchange ( $\mathrm{T}$, humidity, $\left.\% \mathrm{CO}_{2}\right)$, but the largest carbon exchange $(86 \%)$ was obtained on apatite heated at $800{ }^{\circ} \mathrm{C}$ under dry conditions (Hüls et al. 2010). Inorganic carbon dated in calcined archaeological bones would therefore at least partly come from the environmental $\mathrm{CO}_{2}$, which might in some cases have a different ${ }^{14} \mathrm{C}$ activity than carbon originally present in the bone itself. These results were obtained under controlled laboratory conditions, and it was necessary to establish whether these conclusions also apply under natural conditions.

The goal of this study was to quantify crystallographic modifications, as well as stable and radiogenic carbon isotope exchange between bone carbonate and environmental $\mathrm{CO}_{2}$ for bones calcined under natural conditions. Because we worked in natural conditions, it was difficult to spike the fuel $\mathrm{CO}_{2}$. Therefore, we chose to use archaeological bones, in order to maintain a distinct ${ }^{14} \mathrm{C}$ signature between bone carbon and environmental $\mathrm{CO}_{2}$ during combustion.

\section{MATERIAL AND EXPERIMENTAL}

Four archaeological bones ranging in age between the Neolithic and the Medieval period were selected for this study. Details about the fossil bones are summarized in Table 1. The combustion trials took place in a forested area located near the town of Guingamp (Brittany, France) on 5 July 2010. Each bone was combusted on a separate open fire. The 4 hearths were built $\sim 5 \mathrm{~m}$ from each other to avoid cross-contamination. Since we worked under natural conditions, we were not able to distinguish between the influence of atmospheric- and fuel-derived $\mathrm{CO}_{2}$. We therefore decided to use young ( $<5-6$ yr old) wood (Fraxinus sp.) as fuel in order to minimize the ${ }^{14} \mathrm{C}$ age difference between the 2 sources of $\mathrm{CO}_{2}$. This choice led us to recharge the fire frequently in order to keep the fire running. During calcination, breakage of the archaeological bone could occur. We tried to maintain the bone in contact with the hottest part of the fire (embers) and prevent it from settling at the bottom of the hearth where the relatively colder ashes were accumulating. Subsamples of calcined bones were taken every hour for $4 \mathrm{hr}$. The remaining bone fragments were gathered on the following day. 
Table 1 Description of the origin and archaeological context of the 4 bones used in this study.

\begin{tabular}{|c|c|c|c|c|c|c|c|c|c|}
\hline Code & Country & Site name & $\begin{array}{l}\text { Coordi- } \\
\text { nates }\end{array}$ & $\begin{array}{l}\text { Altitude } \\
\text { (m asl) }\end{array}$ & Context & Period & Taxon & $\begin{array}{l}\text { Anatomical } \\
\text { part }\end{array}$ & $\begin{array}{l}\text { Mass } \\
\text { (g) }\end{array}$ \\
\hline AGI & Romania & Agighiol & $\begin{array}{l}45^{\circ} 02^{\prime} \mathrm{N} \\
28^{\circ} 52^{\prime} \mathrm{E}\end{array}$ & 20 & Habitat & Middle Age & Camelus sp. & $\begin{array}{l}\text { Right tibia, } \\
\text { proximal }\end{array}$ & 308 \\
\hline GOL & Mongolia & Egyin Gol & $\begin{array}{l}49^{\circ} 27^{\prime} \mathrm{N} \\
103^{\circ} 30^{\prime} \mathrm{E}\end{array}$ & 885 & Necropolis & Xiongnu & $\begin{array}{l}\text { Homo } \\
\text { sapiens }\end{array}$ & Femur & 145 \\
\hline HAR & Romania & Harsova-tell & $\begin{array}{l}44^{\circ} 41^{\prime} \mathrm{N} \\
27^{\circ} 56^{\prime} \mathrm{E}\end{array}$ & 72 & Habitat & Chalcolithic & Sus scrofa & $\begin{array}{l}\text { Left tibia, } \\
\text { distal }\end{array}$ & 130 \\
\hline MAG & Romania & $\begin{array}{l}\text { Magura } \\
\text { Buduiasca }\end{array}$ & $\begin{array}{l}44^{\circ} 01^{\prime} \mathrm{N} \\
24^{\circ} 25^{\prime} \mathrm{E}\end{array}$ & 60 & Habitat & $\begin{array}{l}\text { ancient } \\
\text { Neolithic }\end{array}$ & Bos taurus & $\begin{array}{l}\text { Right radius, } \\
\text { distal }\end{array}$ & 152 \\
\hline
\end{tabular}

\section{ANALYTICAL METHODS}

The carbon and nitrogen content of total bone, carbon isotope composition of bone collagen, and bioapatite were measured for the unburned and calcined fractions of the 4 archaeological bones. Carbon and nitrogen contents were determined using a CHNOS elemental analyzer (Elementar vario EL III). Precision for $\mathrm{C}$ and $\mathrm{N}$ is better than $\pm 0.1 \%$. Bioapatite samples weighing $\sim 700 \mu \mathrm{g}$ were reacted with $100 \%$ phosphoric acid at $70{ }^{\circ} \mathrm{C}$ for $4 \mathrm{~min}$ in a Kiel IV device, interfaced with a Delta V Advantage isotope ratio mass spectrometer. Analytical precision was $\pm 0.03 \%$ for $\delta^{13} \mathrm{C}(1 \sigma)$ based on repeated analysis of our internal calcite standard (previously calibrated against NBS-19) over the period of analysis.

Fourier transform infrared (FTIR) spectroscopy analyses were performed using the KBr pellet technique following the procedure described in Lebon et al. (2010). Infrared spectra were collected with a Vertor 22 FTIR spectrometer (Bruker) by accumulation of 64 scans with a spectral resolution of $2 \mathrm{~cm}^{-1}$. The crystallinity of the mineral phase was evaluated using the infrared splitting factor (IRSF), following the calculation procedure defined by Weiner and Bar-Yosef (1990). The absorbance of the carbonate band $\left(1415 \mathrm{~cm}^{-1}\right)$ was ratioed to the absorbance of the main phosphate vibration band $\left(1045 \mathrm{~cm}^{-1}\right)$ to obtain carbonate relative contents (Lebon et al. 2010). The ${ }_{2} \mathrm{CO}_{3}$ band contour corresponds to 3 subbands attributed to B-Type $\left(878 \mathrm{~cm}^{-1}\right)$, A-Type $\left(871 \mathrm{~cm}^{-1}\right)$, and labile surface carbonates $\left(866 \mathrm{~cm}^{-1}\right)$ (Rey et al. 1989). These bands where used to determine A/B Type carbonate ratio and the relative content of labile carbonates. The presence of calcite in bone porosities was monitored by the presence of its specific absorption band a $712 \mathrm{~cm}^{-1}$.

The collagen and apatite fractions were dated using accelerator mass spectrometry (AMS). We dated the collagen and apatite fraction from unburned bones because the $2{ }^{14} \mathrm{C}$ ages can potentially differ due to alteration of the apatite phase in temperate environments like Romania (Zazzo and Saliège 2011). We also dated the calcined fraction after 2 and $4 \mathrm{hr}$ of heating, respectively. $\mathrm{CO}_{2}$ was obtained from purified collagen by thermal decomposition at $600{ }^{\circ} \mathrm{C}$ in the presence of $\mathrm{O}_{2}$, and from apatite by orthophosphoric acid attack at $90^{\circ} \mathrm{C}$. The reading of the pressure of $\mathrm{CO}_{2}$ evolved from the sample during the acid reaction was used to estimate bone inorganic carbon content, with a precision of $\pm 0.03 \%(1 \sigma)$.

A sample of wood was also dated using AMS. We dated the $\mathrm{CO}_{2}$ evolved from the combustion of wood at $330{ }^{\circ} \mathrm{C}$ in the presence of $\mathrm{O}_{2}$. Average carbon stable isotope ratios of wood and charcoal were determined using a GV Optima mass spectrometer, based on repeated analysis of 4 and 7 subsamples of wood and charcoal following offline combustion at $330{ }^{\circ} \mathrm{C}$ and $600{ }^{\circ} \mathrm{C}$, respectively, in the presence of oxygen. Graphitization and ${ }^{14} \mathrm{C}$ measurements were performed using the AMS Artemis facility at LMC14 (Saclay, France). 


\section{RESULTS}

\section{Initial Conditions}

Measurements performed on all bones before and after the experiment are summarized in Table 2 . All bones contain extractable collagen but show various states of preservation. Nitrogen content, which is used as a proxy for collagen preservation, varies between 2.0 and $6.7 \%$, above the cut-off value of $0.8 \%$ proposed by Brock et al. (2010) for collagen suitable for ${ }^{14} \mathrm{C}$ dating. Preservation is excellent for GOL and $\mathrm{HAR}$ with $\% \mathrm{C}$ and $\% \mathrm{~N}$ approaching values measured for modern bone, whereas AGI and MAG show the lowest nitrogen contents.

The IRSF values vary from 3.3 to $3.9( \pm 0.1)$ and carbonate contents from 0.15 to $0.30( \pm 0.01)$. The higher IRSF value and lower carbonate content of AGI attest to the more important alteration of the mineral phase in this sample. No trace of calcite is detected in fossil bones at initial state. Following acetic acid treatment, IRSF values increased slightly whereas carbonate contents decreased (excepted for the well-preserved samples HAR for which carbonate content remained stable). This could correspond to the dissolution of smaller or less well-crystallized crystals, or to a loss of carbonate adsorbed at the surface of bone mineral crystallites.

Bone apatite $\delta^{13} \mathrm{C}$ values vary between $-8.8 \%$ and $-15.5 \%$, while collagen $\delta^{13} \mathrm{C}$ values range between $-14.3 \%$ and $-19.7 \%$. The lowest $\delta^{13} \mathrm{C}$ values are typical of a diet dominated by $\mathrm{C}_{3}$ plants, in open (GOL) to more forested environments (HAR). The highest $\delta^{13} \mathrm{C}$ values (AGI, and maybe MAG) could be explained by a small contribution of $\mathrm{C}_{4}$ plants. The ${ }^{14} \mathrm{C}$ activity of the collagen extracted from fossil bones varies between $42.48 \pm 0.19$ fraction modern carbon (F) (MAG) and $97.11 \pm 0.27 \mathrm{~F}$ (AGI). This corresponds to a ${ }^{14} \mathrm{C}$ age between $6880 \pm 35$ and $235 \pm 25 \mathrm{yr} \mathrm{BP}$. We found no significant difference between the ${ }^{14} \mathrm{C}$ age measured on the collagen-bioapatite pairs for the youngest bone (AGI). For the oldest three (GOL, HAR, and MAG), carbonate in apatite was slightly $(0.5 \pm 0.2$ to $1.3 \pm 0.2 \mathrm{~F})$ more radiogenic than collagen. Therefore, isotope exchange between bone carbonate and dissolved inorganic carbon during fossilization appears limited.

\section{Crystallographic and Chemical Changes during Calcination}

Crystallinity values measured for calcined bone samples vary between 5.5 and 8.6. These high IRSF values and the appearance of vibration bands typical for $\mathrm{OH}$ groups $\left(3570\right.$ and $630 \mathrm{~cm}^{-1}$, Figure 1) attest to the recrystallization of bone mineral phase induced by heating. In comparison with crystallinity values observed for experimentally heated modern samples (Lebon et al. 2010), the IRSF values indicate that the samples were exposed to a temperature of between 600 and $700{ }^{\circ} \mathrm{C}$. Whereas no calcite is detected in the fossil samples before calcination, several calcined samples present an absorption band at $712 \mathrm{~cm}^{-1}$ specific to this mineral compound (Table 2). Formation of calcite in bone could come from the absorption of atmospheric $\mathrm{CO}_{2}$ by calcium oxide $(\mathrm{CaO})$, which forms during experimental heating at $>700{ }^{\circ} \mathrm{C}$ (Rogers and Daniels 2002). Alternatively, $\mathrm{CaCO}_{3}$ could also arise from the thermal degradation at $>425^{\circ} \mathrm{C}$ of biogenic calcium oxalate $\left(\mathrm{CaC}_{2} \mathrm{O}_{4}, \mathrm{H}_{2} \mathrm{O}\right.$; whewhellite) present in wood (Brochier and Thinon 2003; Shahack-Gross et al. 2008). This calcite was removed during acid acetic treatment.

The carbonate/phosphate ratio decreased during heating, illustrating the carbonate loss and the recrystallization of the mineral phase induced by calcination. We found an excellent correlation between the inorganic carbon content measured during acid digestion and $\mathrm{CO}_{3} / \mathrm{PO}_{4}$ ratios measured in calcined bones using FTIR $(r=0.97, p<0.001)$, suggesting that this ratio can be used to make quantitative inferences on the amount of carbonate present in fossil bones. Interestingly, the carbon- 


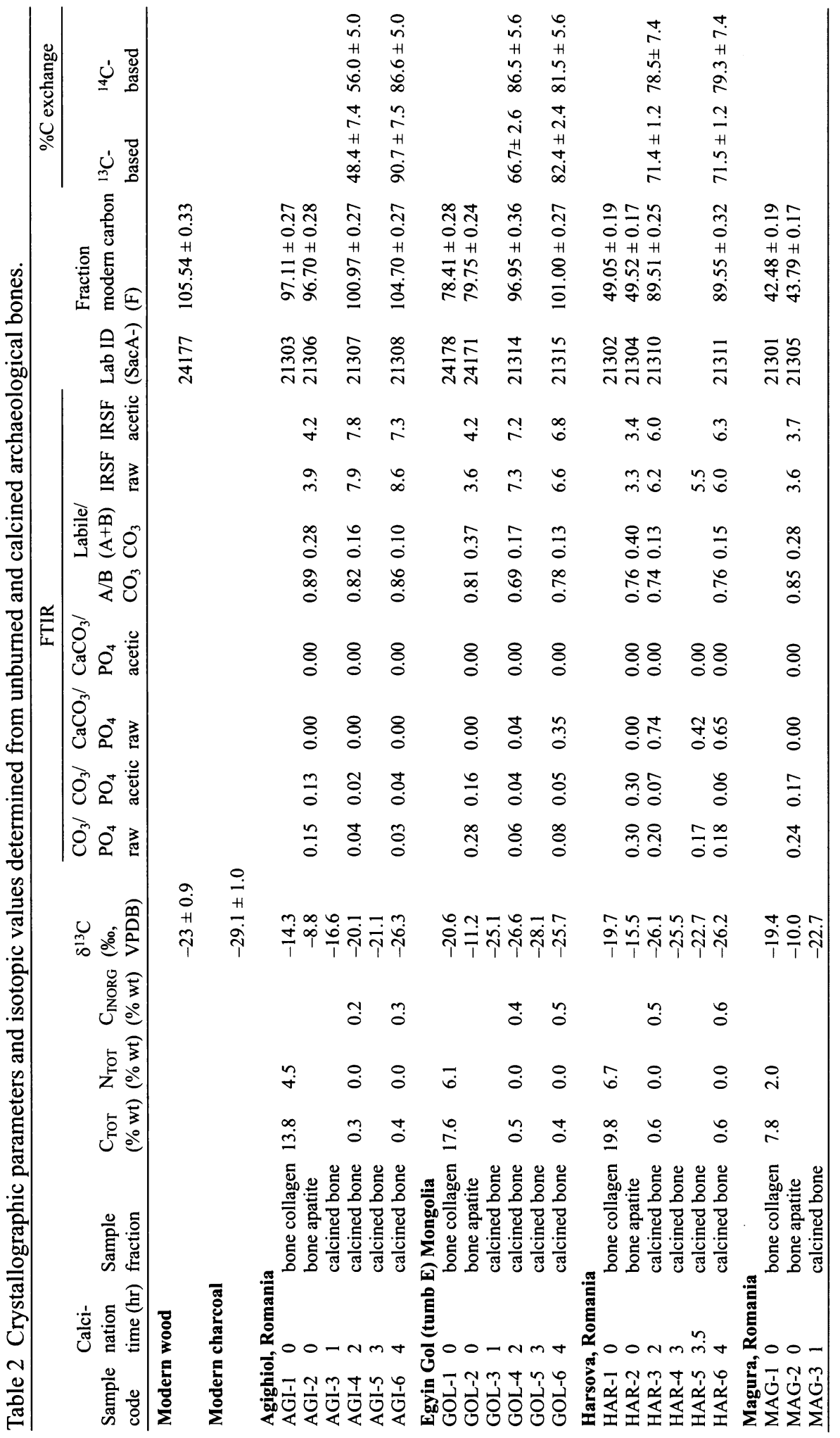



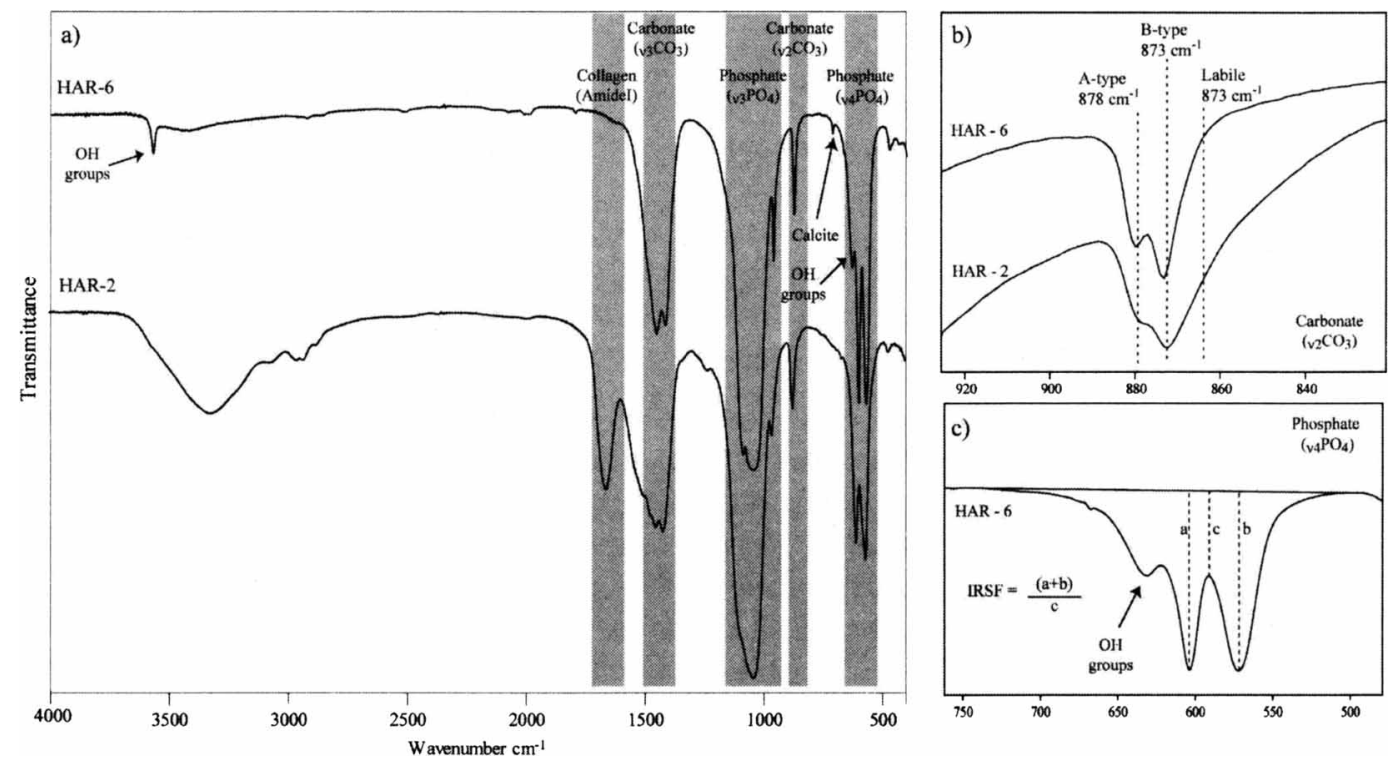

Figure 1 a) General FTIR spectra of a sample before (HAR-2) and after (HAR-4) heating; b) close-up on the $v_{2} \mathrm{CO}_{3}$ domain and the changes induced by heating and position of the bands corresponding to A-type, B-type, and labile carbonates; $\mathrm{c}$ ) close-up on the $\mathrm{v}_{4} \mathrm{PO}_{4}$ vibration bands and procedure for IRSF calculation.

ate content of all samples decreased sharply during the first $2 \mathrm{hr}$ of heating, and then slightly increased in the fractions heated for $4 \mathrm{hr}$ (excepted for HAR whose carbonate content remained stable). The samples showing an increase in their carbonate content also had a higher proportion of Atype carbonate (Table 2), suggesting a preferential incorporation of carbonate in this site. A small increase of labile carbonate content was also observed between 2 and $4 \mathrm{hr}$ of heating for HAR and MAG (Table 2).

\section{Isotopic $\left({ }^{13} \mathrm{C},{ }^{14} \mathrm{C}\right)$ Changes during Calcination}

All the calcined bone samples experience a decrease in their $\delta^{13} \mathrm{C}$ value coupled with an increase in ${ }^{14} \mathrm{C}$ activity (Table 2, Figure 2). The $\delta^{13} \mathrm{C}$ values of calcined bones ranged from -16.6 to $-28.1 \%$, while the ${ }^{14} \mathrm{C}$ activity varied between $89.06 \pm 0.25 \mathrm{~F}$ (MAG-4) and 104.70 $\pm 0.27 \mathrm{~F}$ (AGI-6). Theses shifts are not clearly related to the duration of calcination. One bone shows a regular decrease in $\delta^{13} \mathrm{C}$ values with time (AGI) while the other three do not. The ${ }^{14} \mathrm{C}$ content of calcined bones increased with time for the youngest 2 bones (AGI and GOL), but not for the other two (HAR and MAG). Other factors than just time could play a role, such as local heterogeneity in temperature or $\% \mathrm{CO}_{2}$ exposure between different subsamples of the same bone within each hearth, and could explain this apparent lack of correlation. The magnitude of the maximal stable carbon isotope shift was proportional to the difference between unburned bone and charcoal isotope values $(-29.1 \pm$ $1.0 \%, n=7$ ) and varied between $-10.7 \%$ (HAR) and $-17.5 \%$ (AGI). Similarly, a ${ }^{14} \mathrm{C}$ increase was proportional to the difference between unburned bone and wood $\mathrm{CO}_{2}(105.53 \pm 0.33 \mathrm{~F})$ and was therefore largest for older bones (MAG $\sim 45 \mathrm{~F}$ ).

Calcined bones usually plot along or very close to a mixing line between unburned bone and charcoal ${ }^{13} \mathrm{C}$ and ${ }^{14} \mathrm{C}$ values (Figure 2). Mass balance calculations allow us to estimate the percentage of $\mathrm{C}$ isotope exchange based on stable and radiogenic carbon isotopes results using the following equations: 


$$
\begin{gathered}
\%{ }^{14} \mathrm{C}_{\text {exchange }}=\left(\mathrm{A}_{\mathrm{f}}-\mathrm{A}_{\mathrm{i}}\right) /\left(\mathrm{A}_{\mathrm{atm}}-\mathrm{A}_{\mathrm{i}}\right) \\
\%{ }^{13} \mathrm{C}_{\text {exchange }}=\left(\delta^{13} \mathrm{C}_{\mathrm{f}}-\delta^{13} \mathrm{C}_{\mathrm{i}}\right) /\left(\delta^{13} \mathrm{C}_{\mathrm{atm}}-\delta^{13} \mathrm{C}_{\mathrm{i}}\right)
\end{gathered}
$$

where $A_{i}$ and $\delta^{13} C_{i}$ are the radiocarbon activity and stable carbon isotope ratio of carbonate in unburned bone apatite, $\mathrm{A}_{\mathrm{f}}$ and $\delta^{13} \mathrm{C}_{\mathrm{f}}$ are the radiocarbon activity and stable carbon isotope ratio of carbonate in calcined bone apatite, and $\mathrm{A}_{\mathrm{atm}}$ and $\delta^{13} \mathrm{C}_{\text {atm }}$ are the activity and stable carbon isotope ratio of the atmosphere of combustion. The ${ }^{14} \mathrm{C}$ activity of the charcoal is a good approximation of the activity of the atmosphere of combustion because $\mathrm{CO}_{2}$ concentration near a fire is dominated by $\mathrm{CO}_{2}$ derived from wood combustion (Cousin et al. 2008) and because young wood was used as fuel. We calculated a $\Delta^{14} \mathrm{C}$ value of $48 \pm 3 \%$ for this wood collected in 2010 . This is not significantly different from values measured in Mace Head (Ireland) in 2008, a location under similar Atlantic influence (Levin et al. 2010). The results of these calculations are presented in Figure 3. Very similar estimates are derived from stable and radiogenic isotope results. The carbon exchange ranges between $56 \pm 5 \%$ and $87 \pm 5 \%$ based on $\delta^{13} \mathrm{C}$ values, and between $48 \pm 7 \%$ and $91 \pm 8 \%$ based on ${ }^{14} \mathrm{C}$ values. The correlation between the 2 parameters is good $\left(r^{2}=0.67\right)$. On average, the difference between the 2 estimates is not significantly different from zero $(-6 \pm 8 \%)$.
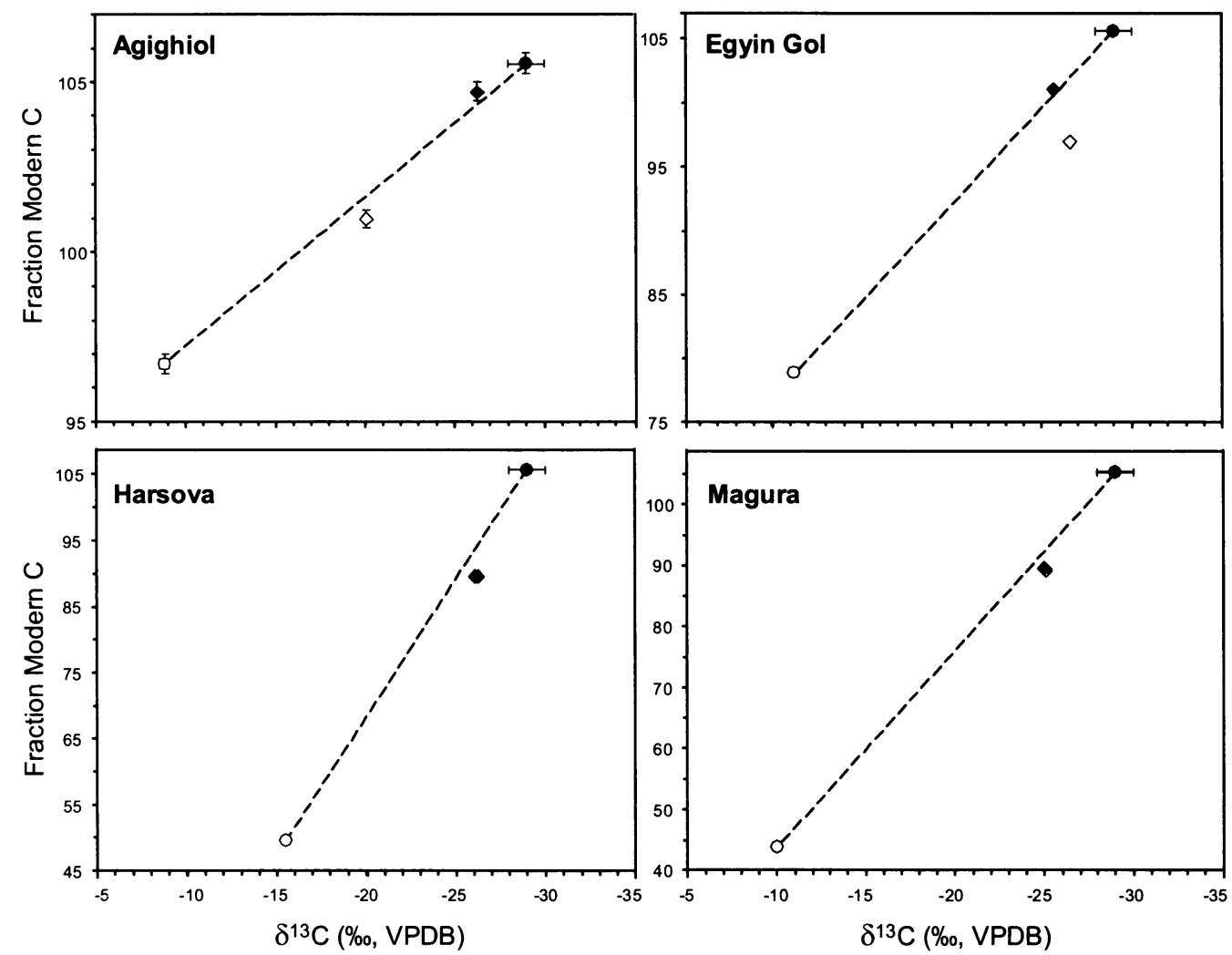

Figure $2{ }^{14} \mathrm{C}$ ages versus $\delta^{13} \mathrm{C}$ values of charcoal (closed circles), unburned bone (open circles) and bone calcined for $2 \mathrm{hr}$ (open diamonds) and $4 \mathrm{hr}$ (closed diamonds). Calcined bones plot near a mixing line (dotted line) between unburned bone and charcoal. 


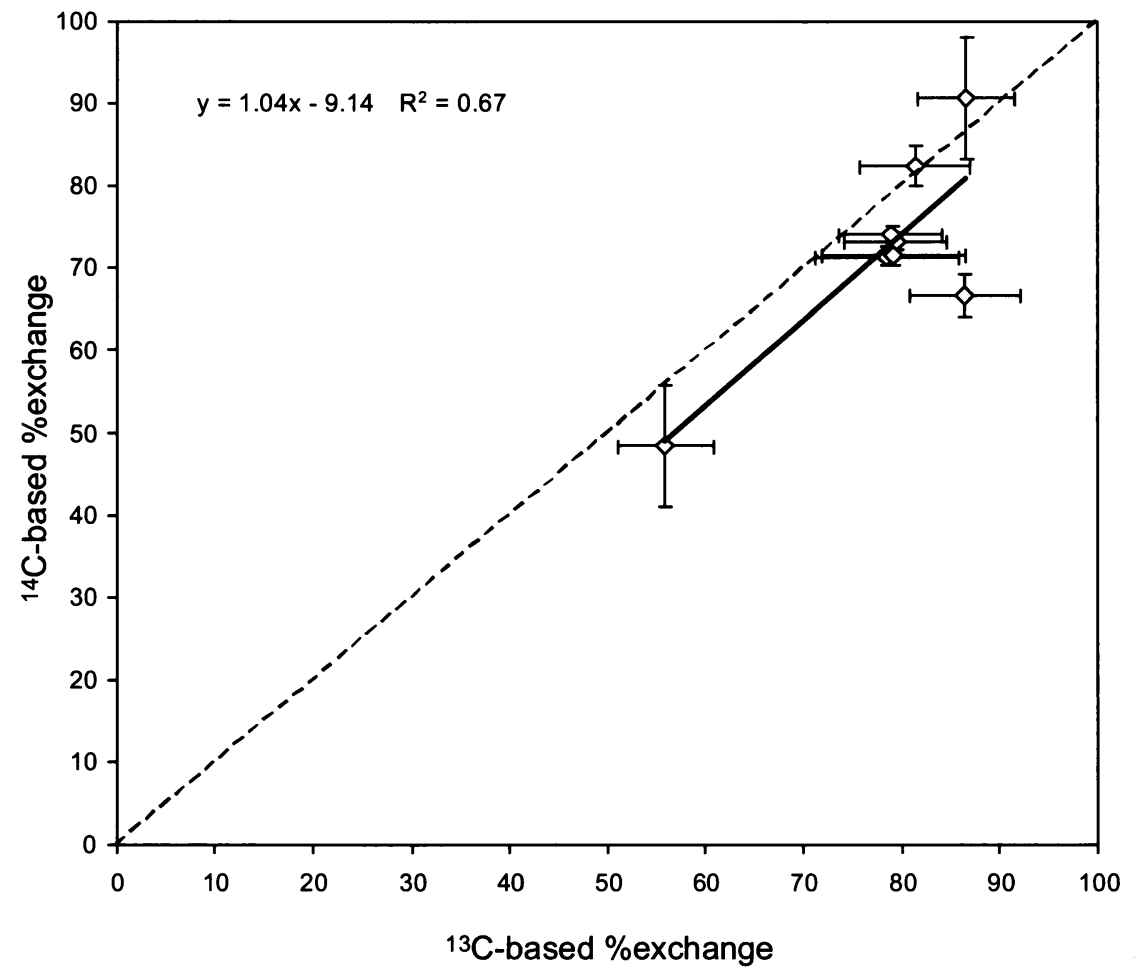

Figure $3{ }^{14} \mathrm{C}$ exchange versus ${ }^{13} \mathrm{C}$ exchange in calcined bones calculated using Equations 1 and 2 (see Results section).

No correlation was found between the amount of carbon in calcined bone and carbon exchange derived from ${ }^{13} \mathrm{C}\left(r^{2}=0.18\right)$ or ${ }^{14} \mathrm{C}$ values $\left(r^{2}=0.03\right)$. $\mathrm{C}$ exchange was not correlated with the age of the fossil ( $r^{2}=0.04$ and 0.00 , based on ${ }^{13} \mathrm{C}$ and ${ }^{14} \mathrm{C}$ values), or with the collagen content, estimated by the $\% \mathrm{~N}\left(r^{2}=0.02\right.$ and 0.00 , based on ${ }^{13} \mathrm{C}$ and ${ }^{14} \mathrm{C}$ values). However, we found that the increase in carbonate content during calcination calculated for GOL and AGI between 2 and $4 \mathrm{hr}$ of heating ( $+35 \%$ and $+61 \%$, respectively) was positively corrrelated with the increase in ${ }^{14} \mathrm{C}$ activity for the same bones $(+22 \%$ and $+88 \%$, respectively).

\section{DISCUSSION}

\section{Carbon Exchange during Calcination}

Rejuvenation of fossil bones calcined under natural conditions demonstrates that the residual carbon present in calcined bones is not pristine and results from isotope exchange between bone carbonate and environmental $\mathrm{CO}_{2}$. This trend was paralleled by low $\delta^{13} \mathrm{C}$ values from $-20 \%$ to $-28 \%$ similar to values found for calcined bones in archaeological contexts (Olsen et al. 2008; Zazzo et al. 2009). In calcined bones with $\delta^{13} \mathrm{C}$ values lower than $-25 \%$, we show that $67 \pm 3 \%$ to $91 \pm 8 \%$ of the carbon present in bone carbonate come from $\mathrm{CO}_{2}$ present in the atmosphere of combustion. This finding confirms earlier results based on laboratory experiments (Hüls et al. 2010; Van Strydonck et al. 2010).

The main advantage of our approach is that it provides conditions closer to those in which bones could have been calcined by ancient populations. Therefore, it allows us to apply our conclusions to 
"real" archaeological samples with more confidence. In contrast to previously published work, we used fossil bones instead of modern bones. One could have expected fossil bones to be less affected by recrystallization than fresh bones for 2 reasons. First, fossil bones have lost a significant part of their organic matter (lipids, protein), which is known to enhance the combustion process and can raise the bone temperature locally (Théry-Parisot 2001). Second, archaeological bones may already be partly recrystallized due to the leaching or the increase in size of smaller crystallites during the fossilization process. High and consistent rates of $\mathrm{C}$ replacement were found for archaeological bones presenting different states of preservations suggesting that collagen degradation or moderate recrystallization does not significantly impact the ability to incorporate foreign carbon during calcination.

These results have serious implications for the interpretation of ${ }^{14} \mathrm{C}$ dates obtained from calcined bones found in archaeogical contexts. The ${ }^{14} \mathrm{C}$ age will only reflect the true age of the bone sample if both the bone and the fuel $\mathrm{CO}_{2}$ have the same ${ }^{14} \mathrm{C}$ activity prior to calcination. We can identify 3 cases where this condition is not met:

1. Calcination of fossil bones. Bones will be reset to a large extent and therefore indicative of the time during which the calcination occurred. In the conditions of our experiment, incorporation of modern carbon in the Neolithic bone of Magura led to a $\sim 6000{ }^{14} \mathrm{C}$ yr rejuvenation of the calcined fraction.

2. Calcination of bones coming from individuals depending on marine resources. Previous research has demonstrated that ${ }^{14} \mathrm{C}$ ages measured on bone collagen as well as carbonate apatite of humans whose diets included regular consumption of aquatic food sources are subject to a reservoir effect (Cook et al. 2001; Yoneda et al. 2002; Munoz et al. 2008). This reservoir effect can reach $500 \mathrm{yr}$ of more in some areas and can be used as a quantitative paleodietary tracer when the local reservoir effect is determined with accuracy (Yoneda et al. 2002). Calcination of such bones with comparatively younger wood would cancel the reservoir effect, making paleodietary inference impossible.

3. Calcination of bones using old fuel (wood, coal). In this case, the combustible is older than the deceased, and the "old wood effect" will be transferred to bone carbonate.

In all cases, ${ }^{14} \mathrm{C}$ ages obtained on coexisting charcoal and calcined bone will remain close to each other. This coherence allowed Lanting et al. (2001) to conclude on the postburial stability of the carbonate in calcined apatite but does not prove that the date obtained from the bone will reflect the true age of the individual.

\section{$\delta^{13} \mathrm{C}$ as a Proxy for $\mathrm{C}$ Isotope Exchange: Implications for Archaeology}

We found that paired $\left({ }^{13} \mathrm{C},{ }^{14} \mathrm{C}\right)$ values measured in calcined bone samples usually plot along or very close to a mixing line between unburned bone and charcoal ${ }^{13} \mathrm{C}$ and ${ }^{14} \mathrm{C}$ values (Figure 3 ). Therefore, the carbon stable isotope ratio of calcined bone provides a good estimate of the percent exchange based on ${ }^{14} \mathrm{C}$. This is in apparent contradiction with Hüls et al. (2010) who found that $\mathrm{C}$ exchange calculated from $\delta^{13} \mathrm{C}$ values was systematically larger (sometimes by more than 20\%) than the exchange based on ${ }^{14} \mathrm{C}$. Different factors such as isotopic fractionation, C-derived collagen, or postburning contamination were invoked to explain these results. It is difficult to directly compare our results with Hüls et al. (2010) because we measured the $\delta^{13} \mathrm{C}$ value of the charcoal, but not from the combustion atmosphere. Experimental data suggest that the $\delta^{13} \mathrm{C}$ value of the volatiles present a large range of variation, which corresponds to the variety of compounds released between $100-1000^{\circ} \mathrm{C}$ (Hall et al. 2008). It would therefore have been difficult to give an estimate of the $\delta^{13} \mathrm{C}$ value of the fuel available to exchange with bone carbonate. Charcoal, however, can be used as a 
proxy for the $\delta^{13} \mathrm{C}$ of the atmosphere of combustion. Combustion experiments suggest that charcoal is usually depleted in ${ }^{13} \mathrm{C}$ by $0-3 \%$ with respect to the source material (Hall et al. 2008). Due to mass balance conservation, $\mathrm{CO}_{2}$ evolved from the combustion wood should be enriched compared to the original material. This is in agreement with the findings of Cousin et al. (2008) who measured a value of $-20 \pm 2 \%$ using laser spectroscopy. This value is higher than the typical value for $\mathrm{C}_{3}$ plants $(-27 \%)$ and can be explained by the degradation of light compounds such as carbohydrates, although mixing with atmospheric $\mathrm{CO}_{2}\left(\delta^{13} \mathrm{C}\right.$ close to $-8 \%$ ) cannot be excluded. We measured a $6 \%$ difference between the $\mathrm{CO}_{2}$ derived from wood at low temperature $(-23.0 \pm 0.9 \%)$ and charcoal at high temperature $(-29.1 \pm 1.0 \%$ ), which confirms previously published results (Cousin et al. 2008; Hall et al. 2008). Even if the fraction evolved at low temperature represents only a subsample of the total $\mathrm{CO}_{2}$, it is likely that the $\mathrm{CO}_{2}$ derived from wood combustion is several \%o higher than charcoal $\delta^{13} \mathrm{C}$ value, which would then conciliate our results with Hüls et al. (2010).

This finding has an interesting consequence. It implies that the proportion of $\mathrm{C}$ exchange can be estimated in calcined bones recovered in archaeological sites using stable carbon isotope values of bone and charcoal. To be successful, this approach requires the $\delta^{13} \mathrm{C}$ value of unburned bone. This value can be measured if the bone is only partly calcined, or if other unburned bones are found nearby and can be associated to the calcined bone. Potentially, this approach could be used to make inferences about the original ${ }^{14} \mathrm{C}$ activity of the bone, provided that estimates regarding the original ${ }^{14} \mathrm{C}$ difference between the bone and the fuel can be proposed. However, large uncertainties are to be expected, and this method will only provide realistic estimates in cases when fuel and ${ }^{14} \mathrm{C}$ age differ significantly. This conclusion holds true for the calcination of dry bone, or of small pieces of fresh bones. We caution, however, that the relationship between $\delta^{13} \mathrm{C}$ value of bone and \% exchange might be more complex to establish in the case of a cremation. During the calcination of a complete body, carbon coming from the organic matter of the deceased (flesh, bone collagen, fat) with potentially different ${ }^{14} \mathrm{C}$ and $\delta^{13} \mathrm{C}$ values than the fuel and air $\mathrm{CO}_{2}$ may exchange with the inorganic bone fraction. Burning experiments using entire (modern) carcasses and fossil fuel may help to address this question.

Stable isotopes can also be used as a (quick) quality check for calcined bones prior to ${ }^{14} \mathrm{C}$ dating. Figure 4 shows an example of this application taken from the Cypriot site of Akrotiri-Aetokremnos dated to $\sim 12,500 \mathrm{cal}$ BP. This site has provided the oldest evidence for human occupation of the Mediterranean islands (Simmons 1999). A small number of pig phalanges showing various degrees of burning were found in association with hearths and stone tools of the occupation layer 2 (Vigne et al. 2009). Since pigs were not originally present on Cyprus and were unlikely to swim over such long distances, the authors concluded that they were introduced by the first settlers by boat. They should therefore have the same age than the charcoal. Collagen was not preserved and ${ }^{14} \mathrm{C}$ ages were measured on the apatite fraction of the unburnt, charred, and partly calcined pig bones. All dates were younger than the charcoal (Figure 4). We interpret this as a result of carbon isotope exchange between bone carbonate and dissolved inorganic carbon during fossilization. The youngest age was obtained on the unburnt bone, and the oldest on the partly calcined bone (Figure 4). In a $\delta^{13} \mathrm{C}$ vs. ${ }^{14} \mathrm{C}$ space, the charred and partly calcined bones plot very near a mixing line between the unburned bone (maximal alteration) and the charcoal (expected age if no alteration). The partly calcined bone plots even closer to the mixing line if we choose the charred bone as the diagenetic endmember. From this result, we can draw 2 conclusions: (1) imperfectly calcined bones can be altered during postdepositional processes and stable isotopes can then be used to select the "best candidates" for ${ }^{14} \mathrm{C}$ dating. This is particularly important for old (pre-Holocene) bones. If no such candidate exists, then $\delta^{13} \mathrm{C}$ values can be used to calculate the proportion of alteration and propose a ${ }^{14} \mathrm{C}$ age corrected from diagenesis. 


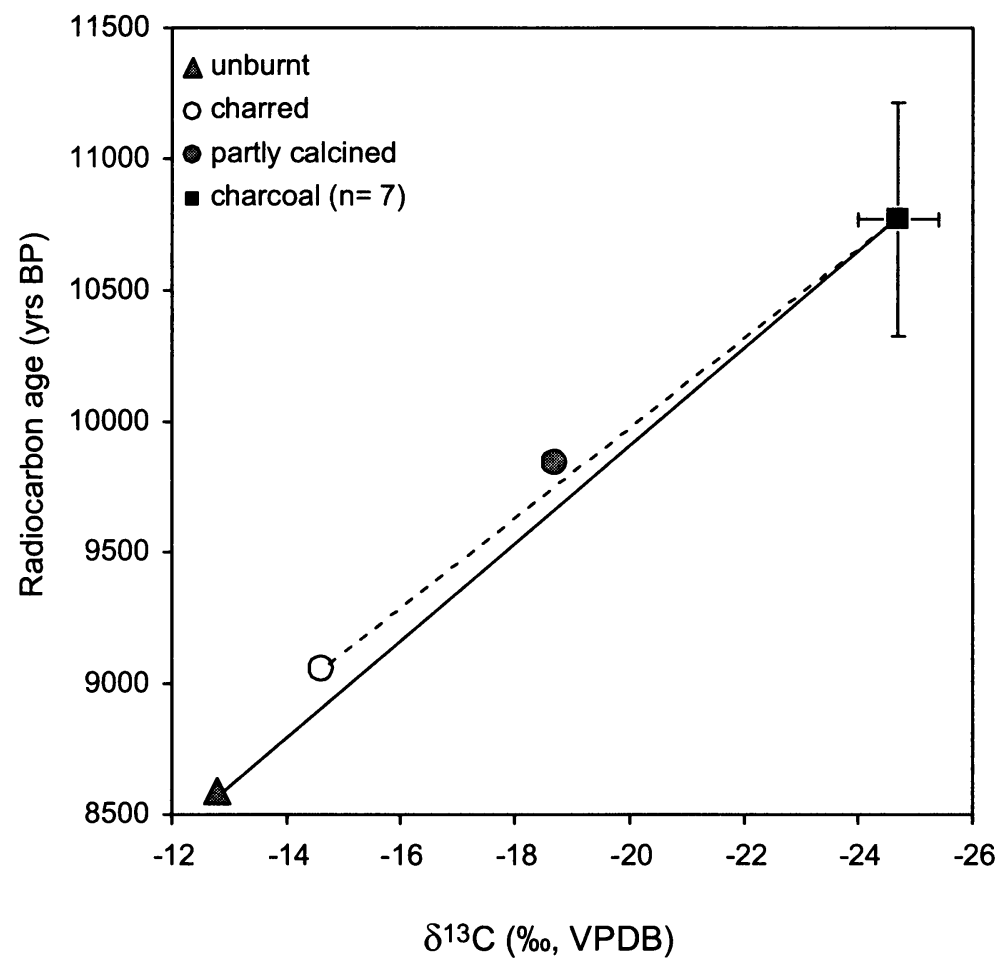

Figure $4{ }^{14} \mathrm{C}$ ages versus $\delta^{13} \mathrm{C}$ values of charcoal and pig bone apatite from AkrotiriAetokremnos (Cyprus). Data can be found in Simmons (1999) and Vigne et al. (2009).

\section{ACKNOWLEDGMENTS}

We are thankful to Adrian Balascescu who provided the archaeological material from Romania and J-D Vigne who provided the archaeological material from Cyprus. We also thank Magloire Mandeng-Yogo (IRD-Bondy, France) for elemental (C, N) analyses, Joël Ughetto (SSMIM, MNHN) for stable isotope analysis of the bioapatite samples, and Clothilde Comby (LMC14, Saclay, France) for graphitization. An anonymous reviewer provided helpful comments to improve the manuscript.

\section{REFERENCES}

Brochier JE, Thinon M. 2003. Calcite crystals, starch grains aggregates or...POCC? Comment on "Calcite crystals inside archaeological plant tissues." Journal of Archaeological Science 30(9):1211-4.

Brock F, Higham T, Bronk Ramsey C. 2010. Pre-screening techniques for identification of samples suitable for radiocarbon dating of poorly preserved bones. Journal of Archaeological Science 37(4):855-65.

Cook GT, Bonsall C, Hedges REM, McSweeney K, Boronean V, Pettitt PB. 2001. A freshwater diet-derived ${ }^{14} \mathrm{C}$ reservoir effect at the Stone Age sites in the Iron Gates Gorge. Radiocarbon 43(2A):453-60.

Cousin J, Chen W, Fourmentin M, Fertein E, Boucher D, Cazier F, Nouali H, Dewaele D, Douay M, Rothman LS. 2008. Laser spectroscopic monitoring of gas emission and measurements of the ${ }^{13} \mathrm{C} /{ }^{12} \mathrm{C}$ isotope ra- tio in $\mathrm{CO}_{2}$ from a wood-based combustion. Journal of Quantitative Spectroscopy and Radiative Transfer 109(1):151-67.

Hall G, Woodborne S, Scholes M. 2008. Stable carbon isotope ratios from archaeological charcoal as palaeoenvironmental indicators. Chemical Geology 247(34):384-400.

Holden JL, Phakey PP, Clement JG. 1995. Scanning electron microscope observations of incinerated human femoral bone: a case study. Forensic Science International 74(1-2):17-28.

Hüls CM, Erlenkeuser H, Nadeau M-J, Grootes PM, Andersen N. 2010. Experimental study on the origin of cremated bone apatite carbon. Radiocarbon 52(2-3): 587-99.

Lanting JN, Aerts-Bijma, AT, van der Plicht J. 2001. Dat- 
ing of cremated bone. Radiocarbon 43(2A):249-54.

Lebon M, Reiche I, Bahain JJ, Chadefaux C, Moigne AM, Fröhlich F, Sémah F, Schwarcz HP, Falguères C. 2010. New parameters for the characterization of diagenetic alterations and heat-induced changes of fossil bone mineral using Fourier transform infrared spectrometry. Journal of Archaeological Science 37(9): 2265-76.

Lepetz S, Van Andringa W. 2008. Les os et le sacrifice: problème de méthode. In: Lepetz S, Van Andringa W, editors. Archéologie du sacrifice animal en Gaule romaine - Rituels et pratiques alimentaires. Archéologie des plantes et des animaux - II; Montagnac: Monique Mergoil éditions. p 11-26.

Lepetz S, Fournet T. in press. Faire feu de tout bois... L'utilisation des os et des déjections animales comme combustible dans les thermes byzantins de Bosra (Syrie du Sud). In: Fournet $\mathrm{T}$ et al., editors. 2011. Third International Balnéorient Conference. 2-6 November 2009, Damas, IFAO.

Lepetz S, Van Andringa W. 2011. Publius Vesonius Phileros vivos monumentum fecit: investigations in a sector of the Porta Nocera cemetery in Roman Pompeii. In: Carroll M, Rempel J, editors. Living through the Dead: Burial and Commemoration in the Classical World. Oxford: Studies in Funerary Archaeology, Oxbow Books. Volume 5. p 10-33.

Levin I, Naegler T, Kromer B, Diehl M, Francey R, Weller R, Worthy D. 2010. Observation and modelling of the global distribution and long-term trend of atmospheric ${ }^{14} \mathrm{CO}_{2}$. Tellus $B$ 62(1):26-46.

Munoz O, Zazzo A, Bortolini E, Seguin G, Saliège J-F, Cleuziou S. 2008. Reconstructing the diet of the ancient fishermen of Ra's al-Hadd and Ra's al-Jinz (Sultanate of Oman) using radiocarbon dates. In: Les Déserts d'Afrique et d'Arabie: environnement, climat et impact sur les populations. Colloque de l'Académie des sciences, Institut de France, 8-9 September, Paris.

Munro LE, Longstaffe J, White CD. 2007. Burning and boiling of modern deer bone: effects on crystallinity and oxygen isotope composition of bioapatite phosphate. Palaeogeography, Palaeoclimatology, Palaeoecology 249(1-2):90-102.

Olsen J, Heinemeier J, Bennike P, Krause C, Hornstrup KM, Thrane H. 2008. Characterisation and blind testing of radiocarbon dating of cremated bone. Journal of Archaeological Science 35(3):791-800.

Person A, Bocherens H, Saliège J-F, Zeitoun V, Gérard M. 1995. Early diagenetic evolution of bone phosphate: an X-ray diffractometry analysis. Journal of Archaeological Science 22(2):211-21.

Rey C, Collins B, Goehl T, Dickson IR, Glimcher MJ.
1989. The carbonate environment in bone mineral: a resolution-enhanced Fourier transform infrared spectroscopy study. Calcified Tissue International 45: 157-64.

Rogers KD, Daniels P. 2002. An X-ray diffraction study of the effects of heat treatment on bone mineral microstructure. Biomaterials 23:2577-85.

Simmons AH. 1999. Faunal Extinction in an Island Society. New York: Kluwer Academic-Plenum Publishers.

Shahack-Gross R, Ayalon A, Goldberg P, Goren Y, Ofek B, Rabinovich R, Hovers E. 2008. Formation processes of cemented features in karstic cave sites revealed using stable oxygen and carbon isotopic analyses: a case study at Middle Paleolithic Amud Cave, Israel. Geoarchaeology: An International Journal 23(1):43-62.

Shipman P, Foster G, Schoeninger M. 1984. Burnt bones and teeth: an experimental study of color, morphology, crystal structure and shrinkage. Journal of Archaeological Science 11(4):307-25.

Théry-Parisot I. 2001. Economie des combustibles au Paléolithique. Dossier de documentation archéologique, CNRS Ed. n²0.

Théry-Parisot I, Costamagno S. 2005. Propriétés combustibles des ossements. Données expérimentales et réflexions archéologiques sur leur emploi dans les sites paléolithiques. Gallia Préhistoire 47:235-54.

Van Strydonck M, Boudin M, Hoefkens M, De Mulder G. 2005. ${ }^{14} \mathrm{C}$-dating of cremated bones, why does it work? Lunula Archaeologia Protohistorica 13:3-10.

Van Strydonck M, Boudin M, De Mulder G. 2010. The origin of the carbon in bone apatite of cremated bones. Radiocarbon 52(2-3):578-86.

Vigne J-D, Zazzo A, Saliège J-F, Poplin F, Guilaine J, Simmons A. 2009. Pre-Neolithic wild boar management and introduction to Cyprus more than 11,400 years ago. Proceedings of the National Academy of Sciences USA 106(38):16,131-8.

Weiner S, Bar-Yosef O. 1990. States of preservation of bones from prehistoric sites in the Near East: a survey. Journal of Archaeological Science 17(2):187-96.

Yoneda M, Tanaka A, Shibata Y, Morita M. 2002. Radiocarbon marine reservoir effect in human remains from the Kitakogane site, Hokkaido, Japan. Journal of Archaeological Science 29(5):529-36.

Zazzo A, Saliège J-F. 2011. Radiocarbon dating of biological apatites: a review. Palaeogeography, Palaeoclimatology, Palaeoecology 310(1-2):52-61.

Zazzo A, Saliège J-F, Person A, Boucher H. 2009. Radiocarbon dating of calcined bones: Where does the carbon come from? Radiocarbon 51(2):1-12. 